\title{
流出土砂が \\ 急傾斜都市氾濫解析に及ぼす影響 \\ EFFECT OF SEDIMENT YIELD \\ ON INUNDATION FLOW ANALYSIS IN HILLSIDE CITIES
}

\author{
川池健司 ${ }^{1} \cdot$ 井上和也 $^{2} \cdot$ 戸田圭一 $^{3}$ ・ 中井勉 ${ }^{4}$ \\ Kenji KAWAIKE, Kazuya INOUE, Keiichi TODA and Tsutomu NAKAI \\ 1学生員 修（工） 京都大学大学院 工学研究科（T606-8501 京都市左京区吉田本町） \\ ${ }^{2}$ 正会員 工博 京都大学教授 防災研究所 （T611-0011 宇治市五ヶ生） \\ ${ }^{3}$ 正会員 Ph.D. 京都大学助教授 防災研究所 （T611-0011 宇治市五ヶ庄） \\ 4学生員 京都大学工学部 （T606-8501 京都市左京区吉田本町）
}

\begin{abstract}
An inundation flow model in hillside cities considering the effects of sediment is developed. In this model, the hydrographs of discharge and sediment concentration calculated in the mountainous area are imposed as the boundary conditions of urban area. In urban area, the two-dimensional inundation flow analysis based on the unstructured meshes is conducted. The above model is applied to Ikuta River basin in Kobe. The obtained results are much severer than those of the case without consideration of sediment. Therefore considering sediment is found out to be very important for inundation flow analysis in the river basin with much sediment yield.
\end{abstract}

Key Words : hillside cities, sediment yield, inundation flow analysis, unstructured meshes, Kobe city

\section{1.はじめに}

1999年, 広島の山間に開けた住宅地で激甚な土砂・ 流木による災害が発生した。2000年の東海豪雨災害 では, 小牧市の住宅が土砂に巻き込まれて死者が出る など, 近年の水害における人的被害の多くは土砂が関 係している. 土砂災害といえば山間部に限られた災害 のように思われがちであるが，1938年（昭和13年）， 1967年（同42年）の神戸，さらに1982年（同57年）の 長崎では, 土砂による汇濫災害が大都市に凄惨な爪痕 を残していった事実がある. 背後に山地が迫っている 比較的傾斜の急な都市では, 土砂災害によって人命が 失われるだけでなく, 都市機能も壊滅的な打撃を受け てしまう.

このような土砂・氾濫災害に対してはハード的対策 のみに頼るのではなく, 住民がその地域の危険性を十 分認知しておくことが被害の軽減につながる，一つの 有力な手段として，土砂災害のハザードマップを作成・ 公表することが考えられるが，それには十分に信頼で きる土砂・汇濫予測手法が必要である. 例えば中川ら 1) は, デカルト座標系モデルを用いた土砂・氾濫解析 手法を提唱している. しかし, 中川らが対象とした領
域は山間部の集落であり, 都市域での氾濫水はこれと は異なる挙動特性を示すと予想される.そこで本研究 では, 非構造格子モデルを用いた二次元氾濫解析を展 開し, 土砂動態を含んだ急傾斜都市での汇濫解析法を 提示するとともに, 土砂の流出が汇濫解析結果に与え る影響を考察した.

\section{2. 氾濫解析法}

本研究で用いる解析モデルは, 対象とする河川流域 を上流側の山地部と下流側の都市部とに分割する.す なわち, 山地部では, 河川から流出してくる流量と土 砂濃度のハイドログラフを求め, その結果を都市部の 上流端での境界条件とする. 都市部では, 上流端で上 記の流量と土砂濃度のハイドログラフを与えて, 2次 元の土砂氾濫解析を行う. ただし, 都市部では適用対 象の特徵から, 河川を掘り込み河道と考えた非構造格 子による解析法を採用する. このようなモデル全体の 概念を図-1に示す。

\section{（1）山地部の解析}

山地部の河川は, 雨水の流出のみを考え土砂の流 

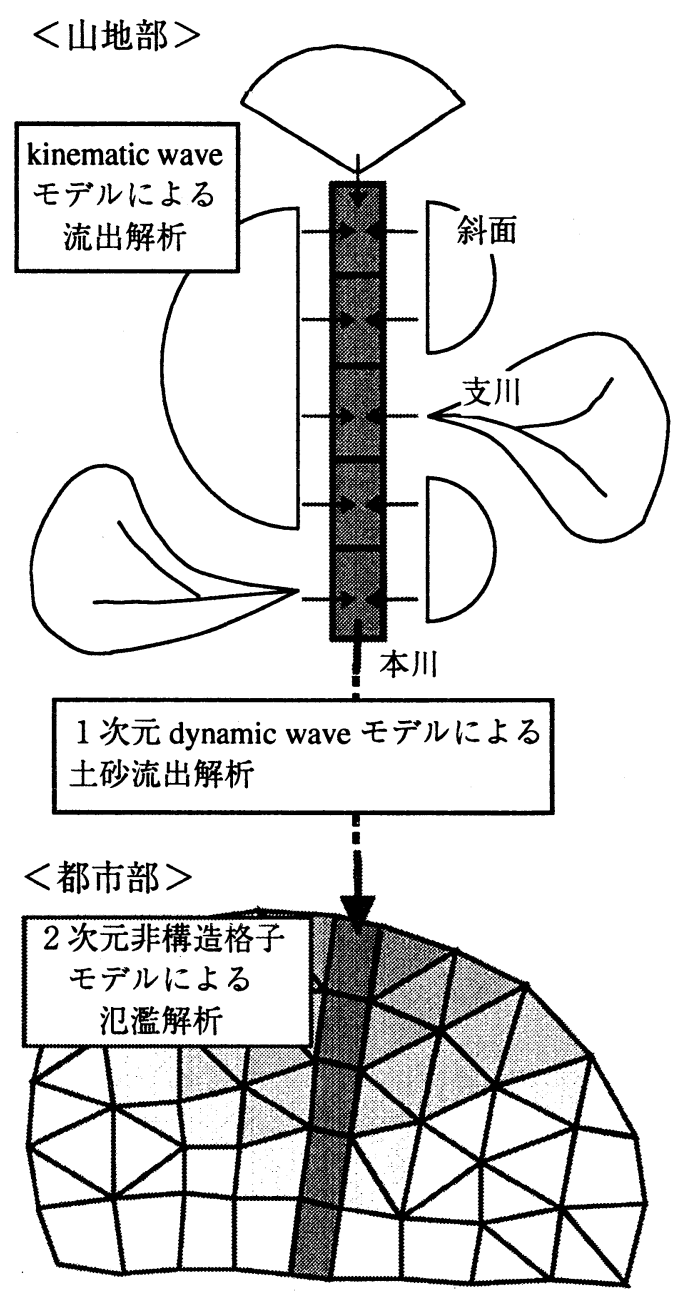

図-1 モデルの概念図

出は考慮しない「支川」と, それが流入して土砂とと もに流出する「本川」とに区分する. はじめに, 直接 本川に流出する斜面および支川からの雨水の流出を kinematic waveモデルを用いて解析する. 次に, 本川 の解析ではそれを横流入流量とし, 土砂の流出も含め た1次元dynamic waveモデルを用いて最下流端での流 量および土砂濃度の時間変化を解析する．ここでは, 山地部の詳細な解析法は参考文献2),3)に譲る.

\section{（2）都市部の土砂氾濫解析}

都市部では，領域を任意形状の非構造格子に分割し， 有限体積法の考え方に基づいてLeap-Frog法による汇 濫解析を進める4). 本研究で用いた未知量は, 図-2に 示すような位直で定義される. すなわち, 全領域に対 してまずデカルト座標系 $(x$ 軸, $y$ 軸) を設定し, この 座標系における各方向の流量フラックス $M, N$, およ び流速 $u, v$ を非構造格子の境界（多角形の辺の中点） で, 流動深 $h$, 土砂濃度 $C$, 土砂堆積厚 $z_{b}$ を非構造格子 の図心（本研究では多角形の重心）で定義する.

都市部で用いる基礎式は, 基本的には中川ら1)の手 法に従い，それを非構造格子に適用する．まず，流れ の連続式と運動量式は以下のとおりである.

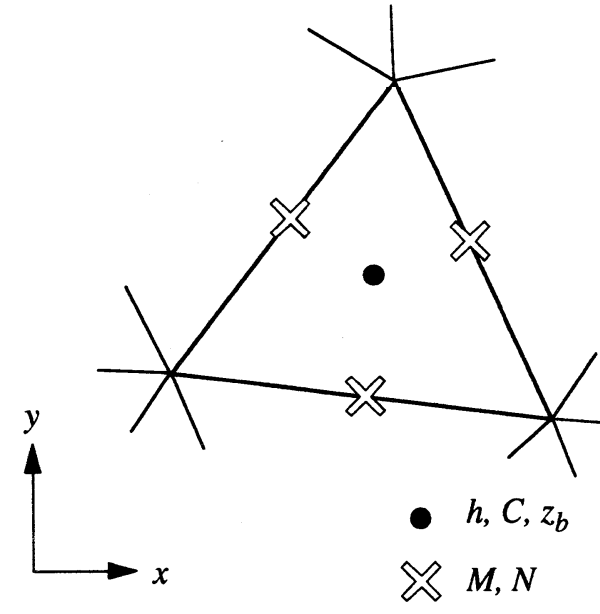

図-2 未知量の定義位置

$$
\begin{gathered}
\frac{\partial h}{\partial t}+\frac{\partial M}{\partial x}+\frac{\partial N}{\partial y}=i+q_{\text {rain }} \\
\frac{\partial M}{\partial t}+\beta \frac{\partial(u M)}{\partial x}+\beta \frac{\partial(v M)}{\partial y}=-g h \frac{\partial H}{\partial x}-\frac{\tau_{b x}}{\rho_{T}} \\
\frac{\partial N}{\partial t}+\beta \frac{\partial(u N)}{\partial x}+\beta \frac{\partial(v N)}{\partial y}=-g h \frac{\partial H}{\partial y}-\frac{\tau_{b y}}{\rho_{T}}
\end{gathered}
$$

ただし, $i$ : 土砂の堆積 (侵食) 速度, $q_{\text {rain }}$ : 降雨強 度, $\beta$ : 運動量補正係数, $H$ : 水位, $g$ : 重力加速度で ある. $\rho_{T}$ は流れにおける水と土砂粒子の混合物の密度 であって, $\sigma$ : 土砂粒子の密度, $\rho_{m}$ : 流体の密度とす ると, $\rho_{T}=\sigma C+(1-C) \rho_{m}$ である. 底面せん断応力 $\tau_{b x}, \tau_{b y}$ には, $C_{*}$ を河床土砂の体積濃度として, 流体 中の土砂濃度の值によって以下の式を用いる。 土石流の場合 $\left(C \geq 0.4 C_{*}\right)$

$$
\begin{aligned}
\frac{\tau_{b x}}{\rho_{T}}=\frac{1}{8} & \frac{\left(\frac{d_{m}}{h}\right)^{2} \cdot}{\left\{C+(1-C) \rho_{m} / \sigma\right\}\left\{\left(C_{*} / C\right)^{1 / 3}-1\right\}^{2}} \\
\frac{\tau_{b y}}{\rho_{T}}=\frac{1}{8} & \frac{\left(\frac{d_{m}}{h}\right)^{2} \cdot}{\left\{C+(1-C) \rho_{m} / \sigma\right\}\left\{\left(C_{*} / C\right)^{1 / 3}-1\right\}^{2}}
\end{aligned}
$$

掃流状集合流動の場合 $\left(0.02 \leq C<0.4 C_{*}\right)$

$$
\begin{aligned}
& \frac{\tau_{b x}}{\rho_{T}}=\frac{1}{0.49}\left(\frac{d_{m}}{h}\right)^{2} u \sqrt{u^{2}+v^{2}} \\
& \frac{T_{b y}}{\rho_{T}}=\frac{1}{0.49}\left(\frac{d_{m}}{h}\right)^{2} v \sqrt{u^{2}+v^{2}}
\end{aligned}
$$

掃流砂の場合 $(C<0.02)$

$$
\frac{\tau_{b x}}{\rho_{T}}=\frac{g n^{2} u \sqrt{u^{2}+v^{2}}}{h^{1 / 3}}
$$




$$
\frac{\tau_{b y}}{\rho_{T}}=\frac{g n^{2} v \sqrt{u^{2}+v^{2}}}{h^{1 / 3}}
$$

ここで, $d_{m}$ : 平均土砂粒径, $n$ : Manningの粗度係数 である.

また, 土砂の堆積速度については, 河川という属性 を与えた格子では侵食・堆積を, その他の格子では堆 積のみを考えることにして

侵食の場合

$$
i=\delta \frac{C_{\infty}-C}{C_{*}-C_{\infty}} \sqrt{u^{2}+v^{2}}
$$

堆積の場合

$$
i=\delta^{\prime} \frac{C_{\infty}-C}{C_{*}} \sqrt{u^{2}+v^{2}}
$$

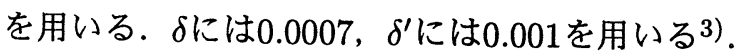

平衡土砂濃度 $C_{\infty}$ については, エネルギー勾配 $\tan \theta$ によって以下のようにして求める.

$\tan \theta \geq 0.138$ のき

$$
C_{\infty}=\frac{\rho_{m} \tan \theta}{\left(\sigma-\rho_{m}\right)(\tan \phi-\tan \theta)}
$$

$0.03 \leq \tan \theta<0.138$ のとき

$$
C_{\infty}=6.7\left\{\frac{\rho_{m} \tan \theta}{\left(\sigma-\rho_{m}\right)(\tan \phi-\tan \theta)}\right\}^{2}
$$

$\tan \theta<0.03$ のとき

$$
C_{\infty}=\frac{(1+5 \tan \theta) \rho \tan \theta}{\sigma-\rho} .
$$

ここで $\phi$ :土砂粒子の内部摩擦角, $\rho$ :水の密度, $\tau_{*}$ およ びて $\tau_{* c}$ はそれぞれ無次元掃流力, 無次元限界掃流力で あり, 以下のようにして計算する。

$$
\begin{gathered}
\tau_{*}=\frac{u_{*}^{2}}{(\sigma / \rho-1) g d_{m}} \\
\tau_{* c}=0.04 \times 10^{1.72 \tan \theta}
\end{gathered}
$$

$u_{*}$ 摩擦速度で, $u_{*}^{2}=g h \tan \theta$ である. さらに, $\bar{\alpha} に つ$ いては,

$$
\bar{\alpha}^{2}=\frac{2\left(0.425-\frac{\sigma \tan \theta}{\sigma-\rho}\right)}{1-\frac{\sigma \tan \theta}{\sigma-\rho}}
$$

とする. ただし, エネルギー勾配 $\tan \theta$ は, 式(4) (9) を用いて

で求める.

$$
\tan \theta \doteq \frac{\sqrt{\tau_{b x}^{2}+\tau_{b y}^{2}}}{\rho_{T} g h}
$$

土砂粒子の連続式は以下の式を用いる.

$$
\frac{\partial(C h)}{\partial t}+\frac{\partial(C M)}{\partial x}+\frac{\partial(C N)}{\partial y}=i C_{*}
$$

さらに河床の連続式には以下の式を用いる.

$$
\frac{\partial z_{b}}{\partial t}+i=0
$$

\section{3. 神戸市への適用}

\section{(1) 対象領域}

本研究の対象領域を含む神戸市街を図-3に示す. 図 のほぼ中央に位置する三宮地区には官庁街や繁華街が あり, 神戸市の中核を成す地域である. 本研究で生田 川を対象としたのは, 生田川がこの三宮付近を流れて いるために, 氾濫が生じた場合, もっとも水害の影響 度が高い河川であると考えたからである.

前章で述べた山地部, 都市部には, 図-3に示す領 域をそれぞれ用いた。すなわち，山地部の領域は新神 戸駅より上流の生田川流域, 都市部は青谷川, 宇治川 をそれぞれ東西の境界とし, 北を居住地域の境界, 南 を海岸線とする領域である. なお，生田川の流域には 含まれていないが雨水が直接都市部に流出する山地 領域を「里山」と呼ぶこととし，その範囲を図-3に 示す. 簡単のため, 本研究では里山からは雨水の流出 のみを考慮し，土砂の流出は考えないことにする．な お, 対象とした山地部, 里山, 都市部の面積はそれぞ れ $10.8 \mathrm{~km}^{2}, 1.5 \mathrm{~km}^{2}, 9.6 \mathrm{~km}^{2}$ であり, 総面積は $21.8 \mathrm{~km}^{2}$ である.

\section{(2) 山地部の解析}

2.(1)の手法を用いて, 山地部からの雨水および土 砂の流出量を計算した. 降雨条件には昭和 13 年水害時 に神戸測候所で観測された毎時雨量を用い, 計算時間 は降雨開始から108時間(4.5日)までとし, $\Delta t=0.1 \mathrm{~s}$ と した.

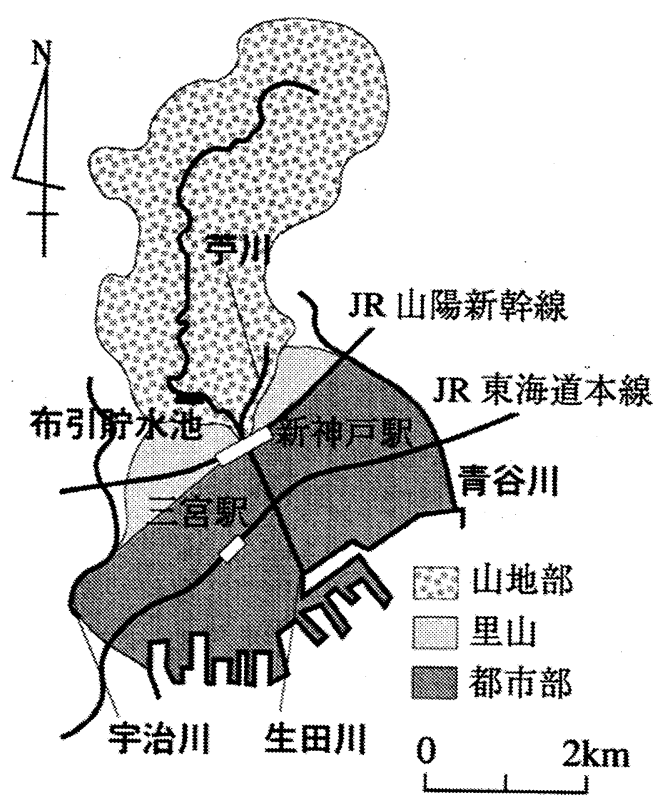

図-3 対象領域図 


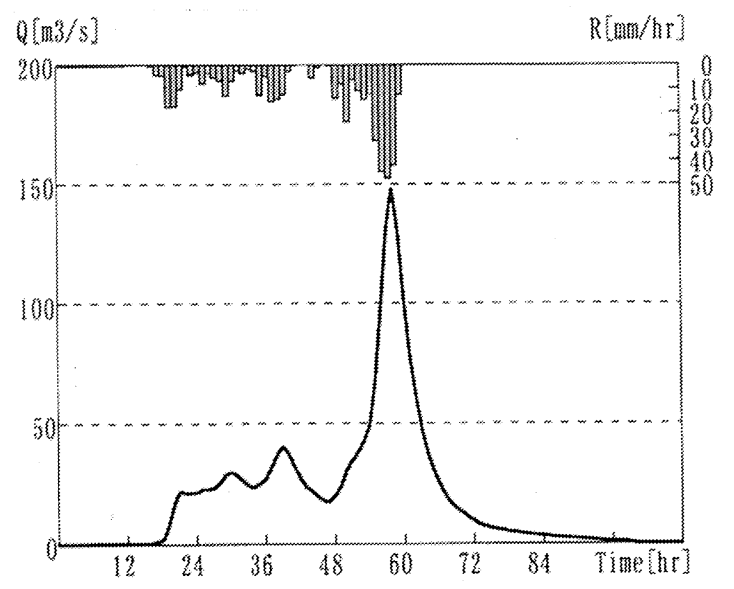

図-4＼cjkstart流量ハイドログラフ（雨水のみ考虑）

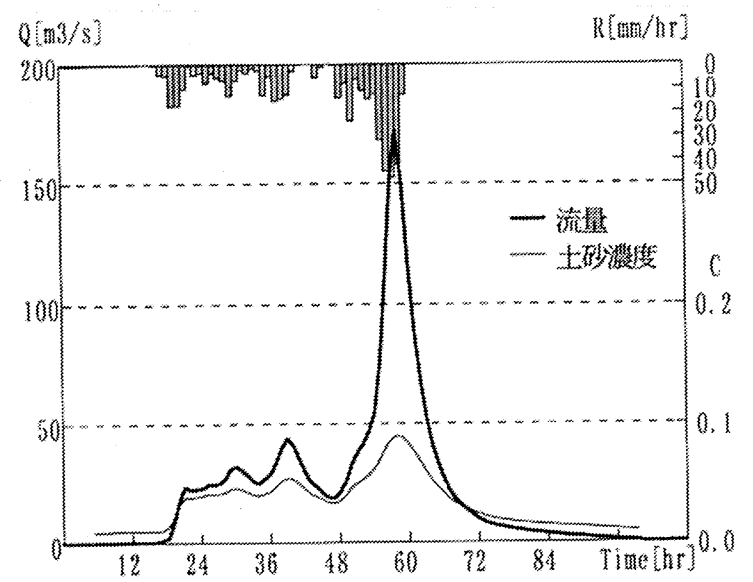

図-5 流量・土砂濃度ハイドログラフ（雨水・土砂考慮）

図-4に雨水の流出のみを考慮した場合の流量ハイ ドログラフを, 図-5に雨水にあわせて土砂流出を考 慮した場合の流量と土砂濃度ハイドログラフをそれぞ れ示す. 雨水だけの場合では最大流量は $148 \mathrm{~m}^{3} / \mathrm{s}$ であ るのに対して，土砂流出を考慮した場合では最大流量 は $170 \mathrm{~m}^{3} / \mathrm{s}$ と大きくなっている.これは，土砂の流出 分が含まれているためである. 昭和 13 年水害時の災 害科学研究所 ${ }^{5}$ の調查によると, 生田川の最大流量は $135 \mathrm{~m}^{3} / \mathrm{s}$ 達しており, これと大きくは異ならない結 果が得られた。

\section{(3) 都市部の解析}

a) 計算条件

本研究で用いた解析格子, ならびに対象領域の地盤 高は図-6のとおりである，格子形成には，生田川の みならず，国道，幹線道路，鉄道などを考慮して領域 を分割した．図一7に河川および道路（鉄道を含む）と して認識した格子を示す. 領域全体の格子数は1844個 で, そのうち河川格子は 27 個, 道路格子は319個であ り, 面積比にすると河川格子が全領域の $0.3 \%$, 道路格 子が同 $9.3 \%$ ある。. 河川格子を除く格子の地盤高は, 神戸市の $1: 2500$ 都市計画図から読み取った值を補間し て作成した．河川格子の地盤（河床）高は，生田川の 横断図より得た $100 \mathrm{~m}$ 間隔の断面積を各河川格子に対

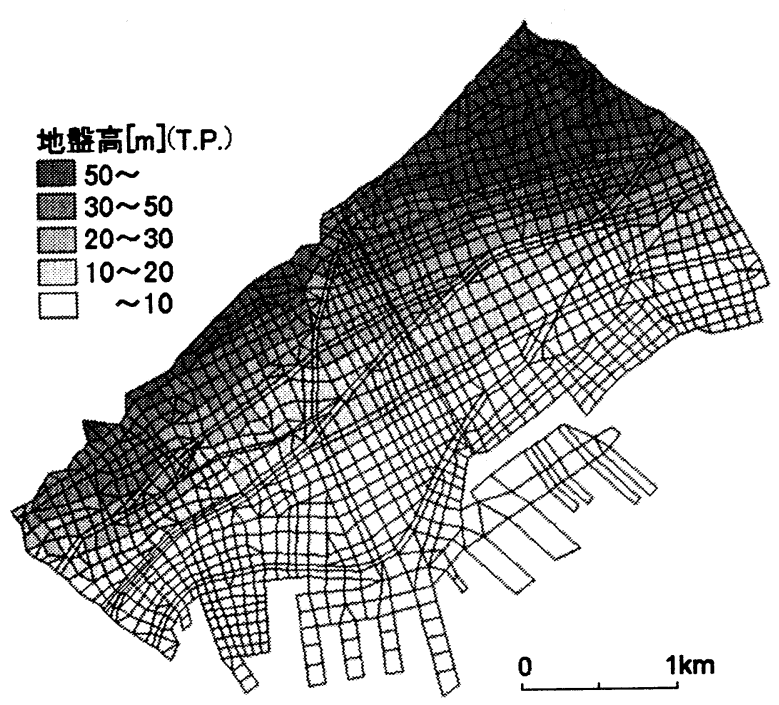

図-6 解析格子と地盤高

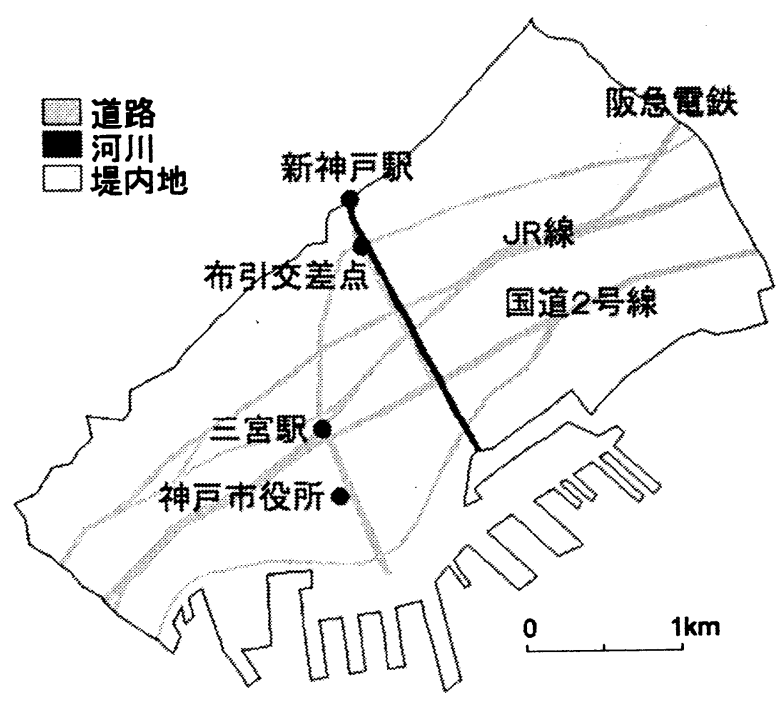

図-7 格子属性（道路・河川・堤内地）

応させ, さらにその格子の平面形状から求められる川 幅より掘り込み深さを決定し, 両岸の格子の平均地盤 高からそれを減じて決定した。

生田川上流端では, 図-4, 図-5に示されるハイド ログラフに従って, 流量フラックスと土砂濃度を境界 条件として与えることにした. 里山と接続している格 子境界では, kinematic waveモデルを用いて得られた 里山からの流出流量を, 流量フラックスに改めて与え た。 その他の領域境界 (下流端の海岸線, および青谷 川・宇治川）では, 格子境界の流量フラックスを $M_{0}$, 境界に隣接する格子の流動深を $h_{1}$ として，段落ち式を 用いて土砂を含む汇濫水を流下させた.

本研究の対象領域は高度に都市化が進んでいるた め, 氾濫の過程において市街地の諸要素の影響を考慮

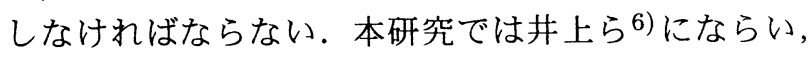
占有率 $\lambda$ と通過率 $\hat{\beta}$ 導入した. すなわち, 河川格子, 道路格子を除く堤内地格子には非浸水性の建造物が存 
在するとし，その面積が格子全体の面積に占める割合 として占有率入を定義した. 本研究では1:2500都市計 画図から読夕取った占有率の平均值 $\lambda=0.64$ を全堤内 地格子に適用した. また, 建造物による汇濫水の遮断 を考慮するため, 通過率を導入するが, 井上ら ${ }^{6}$ )が各 格子中心において通過率を定義していたのに対し，本 研究では, 通過率は流量フラックスと同じ格子境界で 定義するべきであると考え, 堤内地一堤内地, 堤内地一 河川, 堤内地一道路の各格子境界では通過率 $\hat{\beta}$ を 0.35 （1:2500地形図から読みとった值），それ以外の格子境 界は $\hat{\beta}=1.0$ とした.これらの值を用いて，流量フラッ クスを次のように補正した。

$$
M^{*}=\hat{\beta} M, \quad N^{*}=\hat{\beta} N
$$

上式で補正した流量フラックスを用いて，連続式は式 (1)に代わって,

$$
(1-\lambda) \frac{\partial h}{\partial t}+\frac{\partial M^{*}}{\partial x}+\frac{\partial N^{*}}{\partial y}=i+q_{r a i n}
$$

を用いた。ここで降雨強度 $q_{r a i n} に は$ 昭和 13 年水害時の 毎時雨量を用いた．また，土砂粒子の連続式は式(19) に代わって,

$$
(1-\lambda) \frac{\partial(C h)}{\partial t}+\frac{\partial\left(C M^{*}\right)}{\partial x}+\frac{\partial\left(C N^{*}\right)}{\partial y}=i C_{*}
$$

から求めた. さらに, 河床の連続式については, 式(20) の代わりに,

$$
(1-\lambda) \frac{\partial z_{b}}{\partial t}+i=0
$$

を用いた．また，粗度係数 $n$ の值を格子の属性によっ て変化させた.すなわち, 道路格子は福岡ら7)により 0.043 , 河川格子と堤内地格子は通常用いられている 值としてそれぞれ0.020，0.067を用いた。

その他のパラメータについては, $\sigma=2650 \mathrm{~kg} / \mathrm{m}^{3}$, $\rho_{m}=1150 \mathrm{~kg} / \mathrm{m}^{3}, C_{*}=0.65, \tan \phi=0.7$ とし, 平均土砂 粒径は現地にて採取した土砂より $d_{m}=1.14 \mathrm{~mm}$ 用い た. 運動量補正係数 $\beta$ について中川ら1)に従い, 流 れが土石流の場合（式(4)，(5)を用いるとき）は 1.25 , それ以外のときは $1.0 を$ 用いた.なお， $\Delta t=0.5 \mathrm{~s}$ を用い た.

\section{b) 解析結果と考察}

図一8に雨水のみを考慮した場合の最大浸水深図を 示す. 最大浸水深が $0.5 \mathrm{~m}$ 越えるのはごく限られた地 点のみであることから, 土砂生産が盛んなこの領域に おいて土砂を考慮せずに解析を行えば，生田川の汇濫 による被害は総じて小さい結果となった。

次に図-9に雨水と土砂を考慮した場合の最大浸水 深図を, 図-10に計算終了時刻における土砂堆積厚を それぞれ示す. 計算終了時刻における対象領域内の堆 積土砂量の総計は約 40 万 $\mathrm{m}^{3}$ となり, 昭和 13 年当時の 流出土砂量 $\left(48\right.$ 万 $\left.\left.\mathrm{m}^{3}{ }^{5}\right)\right)$ と比較してほぼ同程度となっ
ている．図-10を見ると，土砂の堆積範囲は領域上流 端から扇状に広範囲にわたっている. 新神戸駅から生 田川に沿って約 $1 \mathrm{~km}$ 下流までの地域でおおむね $1 \mathrm{~m}$ 以 上の土砂の堆積が見られ，とくに布引交差点付近にお いては堆積厚は $3 \mathrm{~m}$ 以上なっている。これは, 新神 戸駅から布引交差点にかけて河床勾配が急に緩くなっ ており,この近辺で土砂が堆積しやすくなっているこ とが原因と考えられる.

また, 生田川に沿って数力所から堆積厚の大きい領 域が東西方向に伸びているのがみられるが, 図-7と照 らし合わせるとこの領域は道路格子に沿っていること がわかる. したがって, 土砂は生田川から道路格子に 沿って伝播・堆積していく過程が予測される.

ここで汇濫現象に与える土砂の影響を考えるため に, 図-8と図-9を比較する.土砂を考慮した場合は, 土砂堆積により生田川の河床が上昇するため, 溢水が 生じやすくなり氾濫域が拡大している. 生田川に沿つ た領域のうち, とくに領域の上流部では最大浸水深が 1〜2mも上昇している. したがって, 雨水のみを考慮 した解析で安全と判断された領域の中には, 雨水と土 砂を考慮した解析を行えば危険と判断される領域がか なりあり, 神戸市のように背後に山地を持つ都市を対 象とした汇濫解析においては，土砂を考慮することが 重要な意味をもつことが確認された. またこれらの図 より, 豪雨時の山地部からの土砂流出を抑えることが できれば, 被害が大きく軽減されることもわかった.

b) 阪神大水害時との比較

昭和 13 年の阪神大水害の状況 (図-118) ) と本研究 の解析結果を比較してみると, 昭和 13 年水害時には生 田川左岸ではほとんど浸水しておらず，右岸の旧河道 に沿って氾濫水・土砂が流下して大きな被害を出して いるのに対し，図-9においては両岸で氾濫がみられ， 当時の状況が十分に再現されているとはいえない. そ の原因として, 昭和 13 年当時の生田川が暗渠であった こと, 本研究の解析では流木の影響を無視しているこ となどが考えられる. 現在の生田川流域の地形では, 旧河道に沿って汇濫水が流れるということは考えにく いことから，昭和13年当時には何らかの原因で右岸側 に偏った流れが発生したと思われる。しかし，本研究 の解析では, 生田川の最大流量および流出土砂量が昭 和13年当時の観測值（推定值）と大きくは異なってい ないため, 得られた結果は決して非現実的な規模のも のではないと考えて良いであろう.

\section{4.おわりに}

本研究で得られた成果をまとめれば，以下のように なる.

・土砂の動態をも含めた急傾斜都市における汇濫 解析手法を提示することができた. 


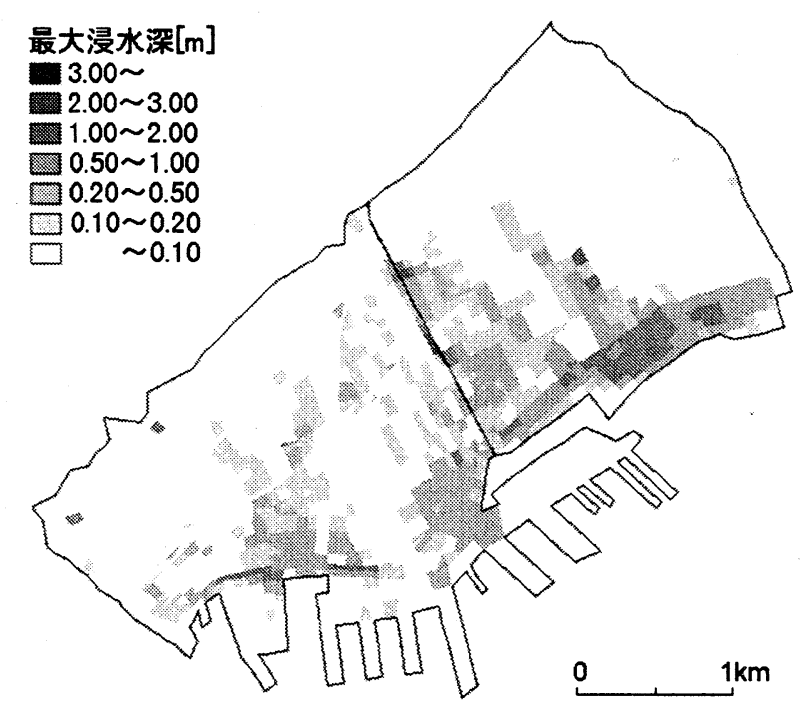

図-8 最大浸水深（雨水のみ）

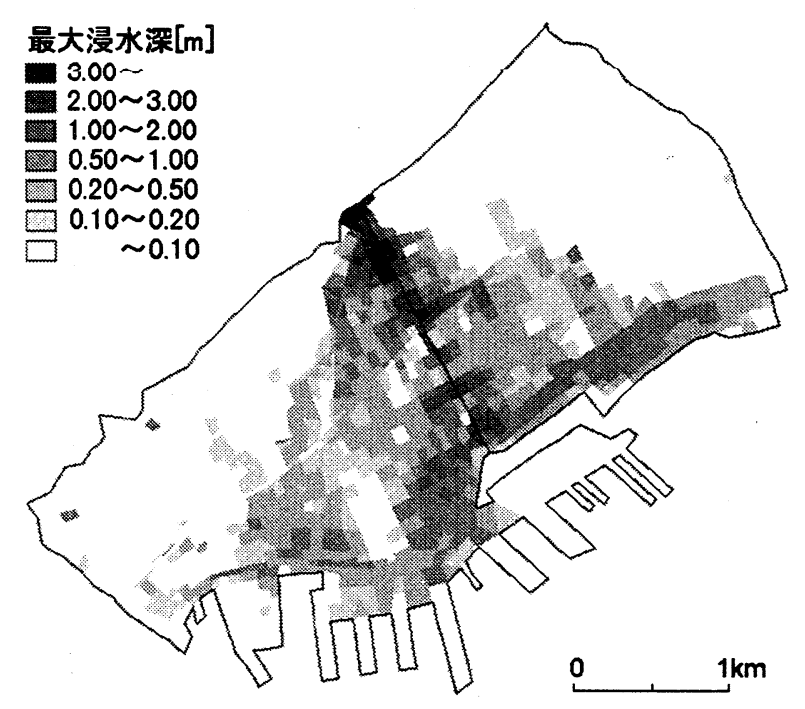

図-9 最大浸水深（雨水・土砂考慮）

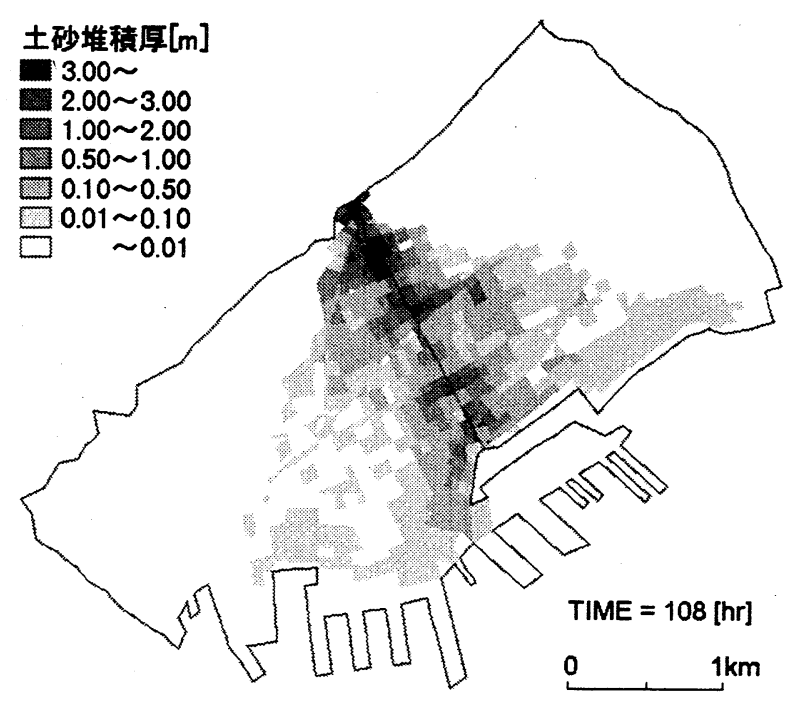

図-10 計算終了時刻の土砂堆積厚

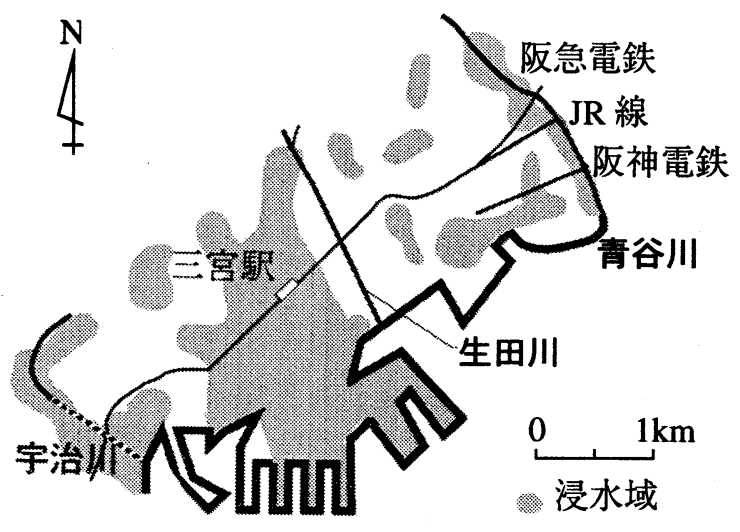

図-11 1938年当時の浸水域 8$)$

-土砂を考慮した場合と考慮しなかった場合の解 析結果を比較することによって, 土砂供給の多 い河川流域の都市域においては, 汇濫水の挙動 が土砂によって大きく影響を受けることが確認 できた。

本研究で提示した解析モデルは，改良の余地はあるに せよ，急傾斜都市における土砂・氾濫災害の予測手法 として有効な情報を与えることができると考えている.

謝辞 : 本研究を進めるにあたり，生田川に関する資料 をご提供下さいました, 兵庫県土木部河川課の方々に 厚く御礼申し上げます。

\section{参考文献}

1) 中川一・高橋保・澤田豊明- 石橋晃睦 : 豪雨性表層 崩壊に起因する土石流の規模予測とGISを用いた避 難行動の解析, 水工学論文集, 第42巻, pp.325-330, 1998.

2) 角屋睦 : 都市化と流出, 水工学に関する夏期研修会, 土木学会水理委員会, pp.A-2-1-A-2-21, 1974.

3) 土木学会編 : 水理公式集例題集, (印刷中).

4) 川池健司・井上和也·戸田圭一:非構造格子の都市氾濫 解析への適用, 水工学論文集, 第44巻, pp.461-466, 2000.

5) 災害科学研究所 : 昭和 13 年災害資料（その3）災害科 学研究所報告 第 1 号, 昭和 13 年 7 月 5 日阪神大水害 調查報告, 1938 .

6) 井上和也・川池健司・林秀樹 : 都市域における氾濫 解析モデルに関する研究, 水工学論文集, 第 43 巻, pp.533-538, 1999.

7）福岡捷二・川島幹雄・松永宜夫・前内永敏 : 密集市街 地の汇濫流に関する研究, 土木学会論文集, No.491 II-27, pp.51-60, 1994.

8）神戸市役所 : 神戸市水害誌, 1939.

(2000.10.2受付) 